\title{
NUMERICAL SIMULATION OF HEAT TRANSFER PROCESSES IN LINING AND OPTIMIZATION OF HEAT WORK OF THE UNIT
}

\section{ЧИСЛЕННОЕ МОДЕЛИРОВАНИЕ ПРОЦЕССОВ ПЕРЕНОСА ТЕПЛОТЫ В ФУТЕРОВКЕ И ОПТИМИЗАЦИЯ ТЕПЛОВОЙ РАБОТЫ АГРЕГАТА}

\author{
UNASPEKOV, Berikbay A. ${ }^{1 *}$; BAZAROV, Ratbek²; AUELBEKOV, Seilkhan S. ${ }^{3}$; IRGIBAEV, \\ Tuleukhan I. 4; SEITKAZINOV, Orazaly D. ${ }^{5}$; KYZYLBAEV, Nurlan K. ${ }^{6}$ \\ ${ }^{1,3}$ Kazakh National Research Technical University of K.I. Satpayev, Department of Engineering Systems and \\ Networks, 22 Satpayev Str., ZIP code 050013, Almaty - Republic of Kazakhstan \\ (phone: + 87016195111) \\ 2,5,6 Kazakh National Research Technical University of K.I. Satpayev, Department of Construction and Building \\ Materials, 22 Satpayev Str., zip code 050013, Almaty - Republic of Kazakhstan
}

(phone: + 87017355969)

${ }^{4}$ Kazakh National Research Technical University of K.I. Satpayev, Department of Oil Engineering

22 Satpayev Str., zip code 050013, Almaty - Republic of Kazakhstan

(phone: + 87016195111)

* Corresponding author

e-mail: unaspekov@yandex.kz

\section{RESUMO}

Com base na modelagem numérica de processos de transferência de calor, as características de transferência de calor e massa no revestimento de um forno túnel de alta temperatura para queimar materiais refratários são reveladas. $\mathrm{O}$ uso de programas modernos de cálculo por computador permite que se escolham os projetos ideais de revestimento de parede e do fundo do carrinho, que garantem um aumento da estanqueidade no espaço de trabalho e uma redução de $15-20 \%$ na perda de calor. A pesquisa da operação do forno túnel de alta temperatura com o desenvolvimento de um sistema combinado para o fornecimento racional da combustão de gás natural e regulação do regime de temperatura no espaço de trabalho da unidade térmica foi realizada. Uma metodologia foi proposta para o cálculo do consumo de combustível pelos queimadores de gás e ar quente a partir das posições das zonas de queima de fornos túnel de alta temperatura usando um sistema combinado de combustão de gás natural. Isto permitiu a otimização da operação térmica do forno túnel, permitindo fornecer a quantidade máxima de ar quente e gás natural para as posições iniciais da zona de queima do forno túnel e atingir a temperatura de queima necessária $\left(1780-1800{ }^{\circ} \mathrm{C}\right)$ de acordo com a tecnologia.

Palavras-chave: forno túnel, revestimento, gás natural, dispositivo ejetor, técnica de cálculo, otimização.

\section{ABSTRACT}

The features of heat and mass transfer inlining of high-temperature tunnel kiln for the burning of refractory materials are revealed by numerical simulation of heat transfer processes. Use of modern computer calculation programs permits to choose optimal constructions of trolley walls and heart lining. This ensures improved hermeticity of workspace and $15-20 \%$ reduction of heat loss. We studied the operation of a hightemperature of the unit with a combined system that ensured efficient burning of natural gas as well as 
regulation of temperature regime in the thermal aggregate workspace. A procedure was advanced to calculate consumption of fuel by gas burners and hot air over burning zone positions of high-temperature tunnel kilns when using a combined system of natural gas burning. The heat work of a tunnel kiln was optimized. This permitted to supply maximal quantity of hot air and natural gas into the initial positions of burning zone of tunnel kiln and to ensure technologically required temperatures of products burning $\left(1780-1800^{\circ} \mathrm{C}\right)$.

Keywords: tunnel kiln, lining, natural gas, ejector system, calculation procedure, optimization.

\section{АННОТАЦИЯ}

На основе численного моделирования процессов переноса теплоты выявлены особенности тепло- и массопереноса в футеровке высокотемпературной туннельной печи для обжига огнеупорных материалов. Использование современных программ компьютерного расчета позволяет выбирать оптимальные конструкции футеровок стен и подины вагонетки, обеспечивающих повышение герметичности в рабочем пространстве и снижение на 15-20\% потери теплоты. Выполнены исследования работы высокотемпературной туннельной печи с разработкой комбинированной системы, обеспечивающей рациональное сжигание природного газа и регулирования температурным режимом в рабочем пространстве теплового агрегата. Предложена методика расчета топлива по газовым горелкам и горячего воздуха по позициям зоны обжига высокотемпературных туннельных печей при использовании комбинированной системы сжигания природного газа. Выполнена оптимизация тепловой работы туннельной печи, позволяющая обеспечить подачу максимального количества горячего воздуха и природного газа на начальные позиции зоны обжига туннельной печи и достижения требуемых согласно технологии температур обжига $\left(1780-1800^{\circ} \mathrm{C}\right)$ изделий.

Ключевые слова: туннельная печь, футеровка, природный газ, эжекторное устройство, методика расчета, оптимизация.

\section{INTRODUCTION}

In recent years the methods of approximate numerical solution of heat conduction equations were being intensely developed. The finite difference method is widely used for PC solving heat conduction equations. The essence of this method is that partial derivatives appearing in the equations are replaced by difference quotients. As a result, the initial partial differential equations are reduced to a system of linear algebraic equations that are solved by iteration methods. Just these methods, along with physical experiments, are now the main instruments to solve the problems of mathematical physics.

An analysis has shown that generally, an approximate method of kiln heat calculation does not take into account the real conditions occurring in commercial aggregates. The characteristic features of most practical problems are multidimensionality and nonlinearity, because of which possibility of an analytical solution of the problems is strongly hampered.

The finite difference method stands out because of simplicity and versatility of its basis and provides high accuracy for results. This method is applicable for the numerical solution of a wide class of tasks (both linear and nonlinear differential equations with different initial and boundary conditions) (Samarskii, 2001).

The integro-interpolation method of construction of difference schemes makes it possible to build homogeneous and conservative through calculation difference schemes that permit solving mathematical physics equations, even with discontinuous coefficients (Sinitsyn et al., 1982).

\section{MATERIALS AND METHODS}

In this work, we applied numerical simulation of kilning aggregates lining. The mathematical model used by us did not take into account heat transfer in the axial and transverse directions with respect to the kiln channel (determined by different structures of the central and peripheral sole parts) as well as heat exchange between the kiln wall and sole through its side face (Utenkov et al., 1991; Tomilin and Chichikalo, 2011; Nikitin et al., 1969). The model of linings of a high-temperature tunnel kiln is presented in Fig. 1.

For numerical simulation of heat 
exchange between kilning aggregates linings, let us consider the Fourier equation at the boundary between the $D$ and $G$ regions (Fig. 1) in Equation 1. With boundary conditions of the first kind, Equation 2, or with boundary conditions of the second kind Equation 3, or with boundary conditions of the third kind Equation 4 , and the initial condition in Equation 5.

Here $T$ is temperature, ${ }^{\circ} \mathrm{C} ; \lambda, C, \rho$ are heat conductivity coefficient, $\mathrm{W} /(\mathrm{m} \cdot \mathrm{K})$, specific heat, $\mathrm{J} /(\mathrm{kg} \cdot \mathrm{K})$ and material density, $\mathrm{kg} / \mathrm{m}^{3}$, respectively; $\mathrm{T}$ is time, $\mathrm{s} ; f(x, y, z, \mathrm{~T}), q_{\Pi}(\mathrm{T})$ and $F(x, y, z)$ are given functions; $n$ is surface normal; $\alpha$ is heat-transfer coefficient, $\mathrm{W} /\left(\mathrm{m}^{2} \cdot \mathrm{K}\right) ; T_{G}$ is gas temperature, ${ }^{\circ} \mathrm{C}$.

Let us suppose that the $D$ region is a rectangular parallelepiped (Equation 6 ) and break up it into planes parallel to the coordinate planes XOY, XOZ, YOZ. The planes intersection points make angles of the net domain $\Omega_{h}$ (Equation 7). $\left\{h_{1}=l_{1} / N_{1} ; h_{2}=l_{2} / N_{2} ; h_{3}=l_{3} / N_{3}\right\}, \gamma_{h}$ is set of nodes $\bar{\Omega}_{h}$ belonging to the $G$ region; $\Omega_{h}$ is set of internal nodes $x_{i}$ belonging to the $D$ region, so that $\bar{\Omega}_{h}=\Omega_{h}+\gamma_{h}$.

Let us apply the integral interpolation method to build a difference scheme for Equations (1)-(6). The left part of Equation (3) is integrated over an elementary volume (Equations $8-9)$. Let us denote heat flux by $\omega=+\lambda(T) \nabla T$. Hence it follows that (Equations 10-12).

Let us express $\omega_{1}, i+1 / 2, j, k$ in terms of values of the $T(x, y, z)$ function in the mesh points. In this case, we have from Equation (10) (Equations 13-14). Integrating $\int_{x_{i-1}}^{x_{i}} \frac{d T}{d x} d x=\int_{x_{i-1}}^{x_{i}} \frac{\omega_{1}}{\lambda} d x \quad$, we obtain. Denoting $a_{i}=\left(\frac{1}{h_{1}} \int_{x_{i-1}}^{x_{i}} \frac{d x}{\lambda\left(x, y_{j}, z_{k}\right)}\right)^{-1}$, we get (Equations 1516). Acting similarly with another summand of the left part and integrating the right part, we obtain a difference scheme (Equations 17-21).

Difference Equation (21) approximates input Equation (1) with approximation accuracy of $\mathrm{O}\left(\mathrm{T}+h^{2}\right)$ where $h=\max \left(h_{1}, h_{2}, h_{3}\right)$.

Let the boundary conditions of the third kind be specified that can be brought to the form (Equation 22).

This notation of the boundary conditions involves also the boundary conditions of the first and second kinds.

Usually, the iteration methods are used to get the numerical solution of difference Equation (21) with boundary conditions Equation (22). One may also apply the alternating direction method. The sweep method is used in each direction.

\section{RESULTS AND DISCUSSION:}

\subsection{Calculation of thermal regime for trolley sole of a tunnel kiln}

In mathematical problem formulation, a sole is considered as a multilayer plate (Fig. 2) whose temperature field is described by $1 \mathrm{D}$ nonstationary heat conduction equation (Equation 23).

It is assumed that, during sole staying in a kiln, the temperature curve of its upper side facing the working channel of sole surface corresponds to the regime burning curve $T_{p}(t)$ (Equation 24).

If a part of the sole stays out of the kiln, then heat exchange in its surface occurs according to Newton's law (Equation 25), where $\alpha$ is total heat-transfer coefficient, $\mathrm{W} /\left(\mathrm{m}^{2} \cdot \mathrm{K}\right)$; $T_{\text {env }}$ is environment temperature, ${ }^{\circ} \mathrm{C}$. In the sole surface facing the environment, heat exchange also occurs according to Newton's law (Equation 26), where / is sole thickness, $\mathrm{m}$.

The total heat-transfer coefficient involves the convective and radiative components (Miheev and Miheeva, 1973) (Equation 27).

Here $A=2.1$ and 3.3 for the lower and upper sole surfaces, respectively; $\varepsilon=5$ is material blackness degree; $\sigma=5.677$ is blackbody coefficient of radiation, $\mathrm{W} / \mathrm{m}^{2} \cdot \mathrm{K}^{4}$. The initial condition is (Equation 28) where $F(x)$ is given function.

Let us consider further finite-difference approximation of heat conduction problem for the sole. Based on the integro-interpolation method, a finite-difference approximation scheme for Equations (21)-(26) will be obtained. Let us introduce a mesh $\omega_{h \tau}=\left\{\left(x_{i}, t_{j}\right), x_{i}=i h, t_{j}=j \tau, i=0, N, j=0,1, \ldots j_{0}\right\}$ with steps $h$ and $\mathrm{t}$ and denote value in the nodes $\left(x_{i}, t_{j}\right)$ by $T_{i}^{j}$. The integro-interpolation method is applied to build a difference scheme. The balanced energy for the cell $x_{i-1 / 2} \leq x \leq x_{i+1 / 2} ; t_{j} \leq t$ 
$\leq t_{j+1}$ is (Equations 29-30). Taking into consideration (Equation 29) and (Equation 30), we obtain an implicit difference scheme (Equation 31).

Approximation of the initial and boundary conditions is as follows (Equations 32-35). We shall use the following designations (Eq. 36). The difference problem (Equations (31-36) is solved by the sweep method. Let us bring (Equation 31) to the following form (Equation 37). With allowance made for (Equation 36), (Equation 38).

The following sweep coefficients are obtained from (Equation 36) to (Equation 39). One can see from Equation (37) that inequality $\left|b_{i}\right|>\left|a_{i}\right|+\left|c_{i}\right|$ (that ensures stability by the sweet method) is obeyed.

The above difference scheme is written for the case when the nodes do not belong to the layer boundaries. If the nodes are at the interfaces between two layers, then the difference scheme is obtained similarly (Equation 40).

The calculations are made in the following sequence:

1. Choice of materials for the lining of trolley wall and hearth.

2. Specification of the starting temperature distribution in the material layer.

3. Calculation of the sweep coefficients as a function of node location.

4. Calculation of the temperature field.

5. Calculation of an error in the temperature field determination due to the temperature dependence of thermophysical properties of materials. If the error exceeds the specified value, then the temperature is calculated again (i.e., item 3 is being performed until the required condition is fulfilled).

6. Determination of specific heat flux going through the upper surface of the sole (Equations 10-12) (Equation 41).

7. Determination of specific heat flux going through the lower surface of the sole (Equation 42).

8. Calculation of sole heat content (Equation 43).

\subsection{Calculation of thermal regime for the wall of a tunnel kiln}

The calculations were made to determine maximal material temperatures and heat flux going through the wall work surface. Shown in Fig. 3 is the construction diagram of tunnel kiln wall. Usually, the wall has five vertical layers; it is thermally insulated from above with two materials and has a horizontal layer (base) below.

Temperature field of the calculated wall element is described by the non-stationary heat conduction equation (Samarskii, 2001) (Equations 44-45), where index $k$ is layer number. If the kiln operates in the non-stationary regime, then the temperature of wall surface facing inside the kiln $(F)$ corresponds to the regime burning curve (Equation 46). If the kiln is considered as a stationary kiln aggregate, then the temperature of this surface is taken equal to the temperature in the kiln at the given area of kiln channel $T_{\Pi}$ (Equation 47). The wall-sole and wall-roof interfaces are considered adiabatic (Equation 48).

Heat exchange at the surfaces facing environment occurs according to Newton's law (Equation 49). The base surfaces located in the ground have the ground temperature (Equation 50).

\subsection{Difference method to solve heat conduction equation}

The alternating direction method was used to solve (Equations 44-49). Let us consider a 2D heat conduction equation (Equation 51 ) with the initial and boundary conditions of Equations (45)-(50) (Equations 52-53). The domain $\Omega=\Omega_{1}+\Omega_{2}+\Omega_{3}+\ldots+\Omega_{6}$; the boundary $F=F_{1}+F_{2}+F_{3}+\ldots+F_{6}$. For each layer a mesh is built according to the general equation (Equations 54-55).

The mesh $\bar{\omega}$ can be considered as a set of nodes located in columns. Therefore, it is possible to get a 1D problem (solving by the by sweep method) in each row at fixed $i$ or in each column at fixed $j$. Such algorithmic idea is expressed by an implicit scheme of alternating directions. An intermediate value $T_{k}^{m+1 / 2}$ is introduced; it may be formally considered to be the temperature $T_{k}$ value at $t=t_{m+1 / 2}$. The transition from the $i_{m}$ layer to the $i_{m+1}$ one is made in two $0.5 \mathrm{t}$ steps. The integro-interpolation methods will be used to build a difference scheme. A separate difference scheme will be built for layer inner and junction points 
(Unaspekov, 1993), as when building a difference scheme for the sole.

At first, let us build a difference scheme for the inner points. The balance equation for the $x_{k i-1 / 2} \leq x \leq x_{k i+1 / 2} ; \quad z_{k j-1 / 2} \leq z \leq z_{k j+1 / 2} \quad$ cell is (Equation 56). Then the integrals and derivatives in these balance equations are replaced by approximate difference expressions. Each summand in (Equation 54) will be considered separately (Equations 57-59). Thus we obtain from (Equation 55) and (Equation 57) an implicit difference scheme (Equation 60). For temporal layer, we obtain similarly (Equation 61). Now a scheme of calculations for layer junction points is built (Equations 62-63). Fixing $i$ or $j$, (Equations 59-62) can be brought to the following form (Equation 64).

Then equations of the Equation (63) form are solved by the sweep method. The calculations are made in the following sequence:

\section{Assignment of the initial data.}

2. Check of the point with indices $(i, j)$ (inner or that at the layer junction).

3. Calculation of sweep coefficients depending on the results of item 2 . If a point is inner, then sweep coefficients are determined from (Equation 61), else from (Equation 62).

4. The calculation in the half-integer step of temperature $T_{k i j}^{m+1 / 2}$ distribution at fixed $j$.

5. Calculation of sweep coefficients versus location point from (Equation 60) and (Equation 62).

6. Fixation of $i$ in the integer step and calculation of $T_{k i j}^{m+1}$ temperature field.

7. Calculation of error in temperature field determination due to the temperature dependence of thermophysical properties of materials. If the error exceeds the given value, then the temperature is calculated again according to the item 2 (i.e., iteration is made).

\section{Determination of heat fluxes.}

A computer program for calculating thermal regime of trolley sole and tunnel kiln wall was made in respect to the high-temperature tunnel kiln of the "Kazogneupor" plant. Numerical experiments were performed to determine the optimal version of trolley wall and hearth. For three versions of trolley, sole constructions see Table 1.
Figure 4 presents the calculation data on temperature variation over the trolley sole section. It is determined that the third of three proposed versions is the most optimal. It ensures lower both heat accumulation by trolley sole and loss into the environment through the walls.

It should be noted that the given filler structures are recommended to be used in hightemperature tunnel kilns with a combined system of gas burning. This makes it possible to reduce heat loss, on the average, by $20-25 \%$.

\subsection{Optimization of heat work of tunnel kiln}

Lack of a reliable method to calculate natural gas and hot air distribution over positions of high-temperature tunnel kilns restrains the implementation of modern gas burning systems as well as optimization of heat engineering processes. It should be noted that the problem of optimization of tunnel kiln heat work is the development of such conditions at which the most optimal temperature chart over the burning zone positions is maintained. The optimal chart of products heating and soaking implies their heating with the maximal technologically acceptable rate, obtaining high burning temperatures and providing long-term aging at this temperature. In such a case, increase in kiln productivity and improvement of products quality are ensured, with simultaneous reduction of the specific fuel consumption rate (Shibalov, 2004). That is why high-temperature small tunnel kilns with a combined gas burning system are promising: they provide the required kiln heat regime.

The aim of making up a heat balance of a high-temperature tunnel kiln is to determine the total natural gas consumption per tunnel kiln.

Heat income:

1. The heat of fuel (Equation 65) where $B$ is natural gas consumption, $\mathrm{m}^{3} /$ hour; $Q_{\mu}^{p}$ is gas heat capacity, $\mathrm{kJ} / \mathrm{m}^{3} .2$. Physical heat from natural gas (Equation 66), where $C_{T}$ is natural gas heat capacity, $\mathrm{kJ} / \mathrm{kg} \cdot \mathrm{deg} ; t_{T}$ is natural gas temperature, ${ }^{\circ} \mathrm{C}$ (Schulz, 2002).

3. The heat coming to the burning zone (Ansimov et al, 2013) from air entering:

a) from the environment (Equation 67) where $V_{B}$ is air amount required for complete 
burning of natural gas, $\mathrm{m}^{3} /\left(\mathrm{m}^{3}\right.$ of gas $) ; t_{B}$ is air temperature; $C_{B}$ is air heat capacity, $\mathrm{kJ} / \mathrm{m}^{3}$; $\alpha$ is excess air coefficient;

b) from the cooling zone (according to practical data, about one-third of stoichiometric) (Equation 68).

4. Products heat (Equation 69) where $P$ is kiln productivity; $t_{\mathrm{pr}}$ is the temperature of products entering from driers into the kiln.

5. The heat coming from the trolley lining (Equation 70), where $G_{c h}, G_{c}, G_{k . l}, G_{c h . l,}$ and $G_{u . k}$ are masses of chrome-magnesite, corundum, kaolin lightweight, chamotte lightweight and chamotte crumb of the trolley hearth layers, respectively.

6. The heat of excess air intaking in the heating zone (Equation 71) where $\alpha_{o g}$ is air excess coefficient in outgoing gases.

Heat consumption:

7. Heating of products to the burning temperature (Equation 72), where $C_{p r}$ is average heat capacity of calcined products over a period of thermal treatment.

8. Heat loss through heat accumulation by the trolley hearth (Equation 73), where $q_{m}^{B}$ and $q_{0}^{b}$ is heat content at a moment $m$ and in the initial period, respectively.

9. Loss with outgoing gases (Equation 74) where $V_{c p r}, C_{c p r}$, and $t_{o g}$ are volume and heat capacity of combustion products and temperature of outgoing gases, respectively.

10. Loss by heat conduction into the environment through the side walls, kiln roof, and trolley hearth. Calculation is performed by the method of successive approximations with the formula (Equation 75) where $t_{i s}$ and $t_{a a}$ are temperature of the masonry inner surface and ambient air around kiln, respectively; $\delta_{1}$, $\delta_{2}, \ldots, \delta_{i}$ and $\lambda_{1}, \lambda_{2}, \ldots, \lambda_{i}$ are thicknesses of refractory masonry layers and their heat conduction, respectively; $\alpha_{0}$ is coefficient of heat emission by free convection from the outer surface of kiln lining into environment (Biryukov, 2012); $F$ is area of wall surface, roof or trolley.

It is taken into account that fuel is completely burned, i.e., there are no $\mathrm{CO}, \mathrm{H}_{2}$, and
$\mathrm{CH}_{4}$ in combustion products (fuel underburning was practically not detected). By and large, the consumption $B$ of natural gas per hightemperature tunnel kiln (at a chosen amount of hot air coming from the cooling zone into the burning zone) is determined from the heat balance equation $Q_{\text {income }}=Q_{\text {consumption. }}$. The results of heat balance calculation are presented in Table 2. The determined consumption of natural gas per kiln is $80 \mathrm{~m}^{3} /$ hour.

\subsection{Heat balance of burning zone positions and determination of hot air and natural gas consumption}

The position heat balance has both heat income and consumption items. For the burning zone position, the heat balance equation is (Equation 76). Here $B_{i}$ is natural gas consumption over kiln positions; $q_{h a}=C_{h a} \cdot t_{h a} \cdot V_{h a}$ is specific heat of hot air; $Q_{u}^{i}$ is heat consumed by calcined products at the $i$-th position; $Q_{r}^{i}, Q_{w}^{i}, Q_{t r}^{i}$ - heat lost through the roof, walls and with trolley that involves heat accumulated by the trolley hearth and that lost through the hearth due to heat conduction; $Q_{\text {diss }}^{i}$ is heat lost by dissociation of combustion products at the $i$-th position.

The proposed procedure (Unaspekov, 2001; Unaspekov, 2014; Unaspekov et al., 2002) makes it possible to calculate consumption of natural gas over gas burners and hot air over burning zone positions of small high-temperature tunnel kilns (using a combined system) with known geometric sizes of a channel in the kiln wall for hot air takeoff, as well as jet devices at the positions, type of gas burners and their location over the burning zone length (Mendheim, 1978; Walter et al., 1975; Avdeeva, 1971). The calculation is performed with allowance made for the technologically required temperature of products burning, as well as temperature and amount of hot air coming from the cooling zone.

To obtain the required burning temperature, it is necessary to determine the amount of hot air coming into the ejector systems from the cooling zone, as well as natural gas consumption over gas burners of the burning zone positions (Utenkov et al.; Unaspekov, 1997). The calculations take into account distinctions in heat loss at the burning zone positions that are compensated for by the corresponding supply of natural gas. The sequence of calculations is as 
follows.

1. Determination of the total gas consumption per tunnel kiln based on making up a heat balance of a high-temperature tunnel kiln.

2. Making up heat balances for every position of burning zone and determination of gas consumption from the following dependence (Equation 77).

Here $V_{G}$ is gas consumption per kiln, $\mathrm{m}^{3} /$ hour; $Q_{m}^{i}$ is heat accumulated by material at the $i$-th position, $\mathrm{kJ} /$ hour; $\sum Q_{n}^{i}$ is total heat loss at the kiln positions through walls, roof and with trolley hearth, kJ/hour; $Q_{\text {diss }}^{i}$ is heat lost for combustion products dissociation, kJ/hour; $\sum_{0}^{i=1} V_{c p r}$ is total volume of combustion products coming to the (i-1)-th position from the $i$-th position, $\mathrm{m}^{3} /$ hour; $Q_{H}^{p}$ is gas burning heat, $\mathrm{kJ} / \mathrm{m}^{3}$; $\alpha_{i}$ is coefficient of air consumption at the $i$-th position; $V_{o}$ is theoretically required amount of air for gas burning, $\mathrm{m}^{3} / \mathrm{m}^{3}$; $J_{a h}$ is air heat content at a temperature of the $i$-th position.

3. Calculation of relative heat removal from a flare at the burning zone positions from Equation 78.

4. Determination of heat amount $Q_{h a}$ required to obtain required burning temperatures from Fig. 5 (with allowance made for the known $\Delta \bar{t}$ and $t_{\text {burn }}$ values).

5. Determination of specific amount of hot air from the formula (Equation 79).

6. Calculation of the required amount of hot air over the burning zone positions (Equation 80).

7. Calculation of specific amount of initial air with the further calculation of initial air consumption over gas burners of the burning zone position (Equation 81).

Practice of an operating high-temperature tunnel kiln equipped with a system for hot air removal demonstrates considerable effect on hot air distribution over the burning zone positions from the following factors: burners location relative to the ejector confuser; gas-dynamic parameters of gas burners mounted on the burning zone positions; temperature of oxidant taken off from the cooling zone.

\section{CONCLUSIONS}

1. We propose a mathematical model for linings of a high-temperature tunnel kiln and a computer calculation program. They permit to calculate and choose an optimal building and heat-insulating materials that ensure the improvement of aggregate working space hermeticity and $15-20 \%$ reduction of heat loss. The advices are given on how to use modern materials for lining constructions when building new and upgrading the existing tunnel kilns.

2. Based on the investigation of hightemperature tunnel kiln operation, we established the main parameters of a system that ensures efficient burning of natural gas and regulating temperature regime of a heat aggregate.

3. We propose a method to calculate a combined gas burning system making it possible to determine the main parameters of ejector systems as well as aerodynamic operating conditions of gas burners and tunnel kiln in whole.

4. Optimization of heat work of a tunnel kiln is realized in practice. Its novelty involves the supply of a maximal amount of hot air and natural gas (uniformly mixed by ejector systems) into the initial positions of burning zone of a tunnel kiln. This operating condition for a high-temperature tunnel kiln with combined heat and gas supply differs radically from the traditional kiln regimes: it promotes obtaining technologically required burning temperatures (to $1800^{\circ} \mathrm{C}$ ) and long-term soaking in the working space. In this case, the tunnel kiln productivity increases by $10-15 \%$ and $20-25 \%$ saving of natural gas are ensured.

\section{REFERENCES}

1. Ansimov A. A.; Merker E. E.; Kharlamov D. A.; Kochetov A. I.; Kazartsev V. O. Bulletin of Cherepovets State University, 2013, 1 (2), 59.

2. Avdeeva A. A. Control of combustion of gaseous fuel. Moscow: Energia, 1971.

3. Berdyshev V. F.; Bosenko A.V.; Naidenov R.E.; Sarkisova V. G.; Shatokhin K. S. In: Metallurgical Heat Engineering: Collection of scientific works of the National Metallurgical Academy of Ukraine. Dnipropetrovsk: Porohy, 2005, 400-404.

4. Biryukov A. B. Energy efficiency and quality of thermalprocessing of materials in furnaces. Donetsk: "Noulidge" Publishing House, 2012. 
5. Mendheim J. Interceram, 1978, 27(1), 6466.

6. Miheev M. A.; Miheeva I. M. Heat Transfer Principles, Moscow: Energiya, 1973.

7. Nikitin B. C.; Zabrodsky S. S.; Antonishin N. V. Engineering and Physics Journal, 1969, 15(4), 726-730.

8. Samarskii A. A. The Theory of Difference Schemes, New York: Marcel Dekker, Inc., 2001.

9. Schulz L. A. Izvestia Vuzov, Chernaya Metallurgiya, 2002, 7, 64-69.

10. Shibalov S. N. Improvement of thermal processes to improve the quality of billets from carbonaceous materials. PhD Thesis. Moscow: National University of Science and Technology, 2004.

11. Sinitsyn E. A., Zvyagintsev K. N., Utenkov A. F., Kirichenko S.M., Vipal Keramiky, 1982, 3, 33-43.

12. Tomilin E, M.; Chichikalo N.I. Methodology for determining the temperature state of the through-flow furnaces. Donetsk: "Noulidge" Publishing House, 2011.

13. Unaspekov B. A. Gas Supply: A Tutorial, Almaty: ENU, 2014.

14. Unaspekov B. A., Optimization of thermal regime of a high-temperature tunnel kiln with combine system of gas heating. Building Constructions and Structures Safety (Intercollegiate collected transactions), Almaty: KazGASA, 1993.

15. Unaspekov B. A. Search. A series of natural and technical sciences, 2001, 2, 14-16.

16. Unaspekov B. A. Use of Gas in Industrial Kilns Producing Building Materials, Almaty: KazGASA, 1997.

17. Unaspekov B. A.; Utenkov A.F.; Albul V.P. Optimization of Heat Engineering Processes of High-temperature Industrial Kilns, Almaty: KazGASA, 2000.

18. Utenkov A. F.; Kornienko A. B.; Unaspekov B.A.; Domrachev N.A.; Okudin V.M. Tunnel Kiln, Author's Certificate USSR 1502936.

19. Utenkov A. F.; Unaspekov B. A.; Kornienko A. B. Industry of building materials of Moscow, 1991, 8, 9-10.

20. Walter G.; Steinhardt R.; Neumann J. Energie Anwendung, 1975, 24, 19-22. 


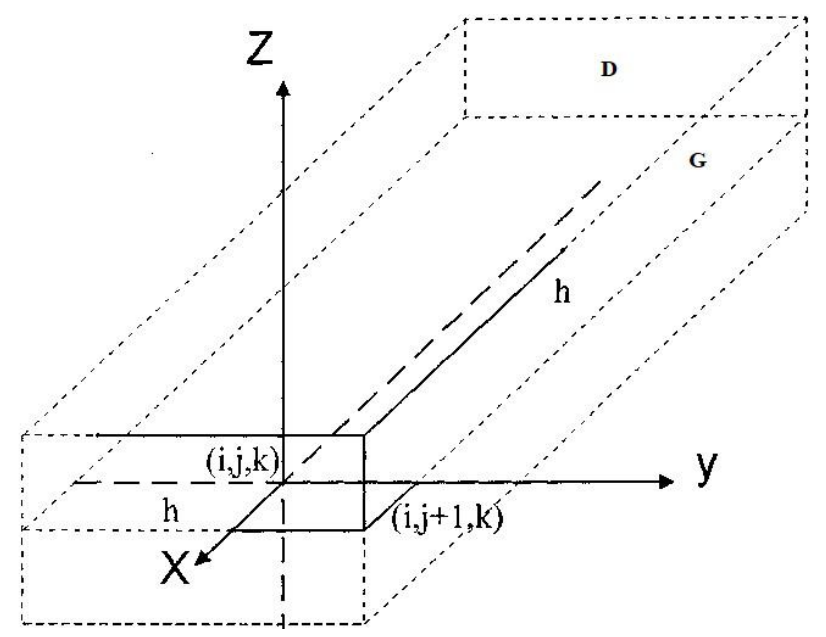

Figure 1. A diagram of a kiln lining model: $G, D$ - heating regions; $h$ - nodes; $X, Y, Z$ - coordinate axes

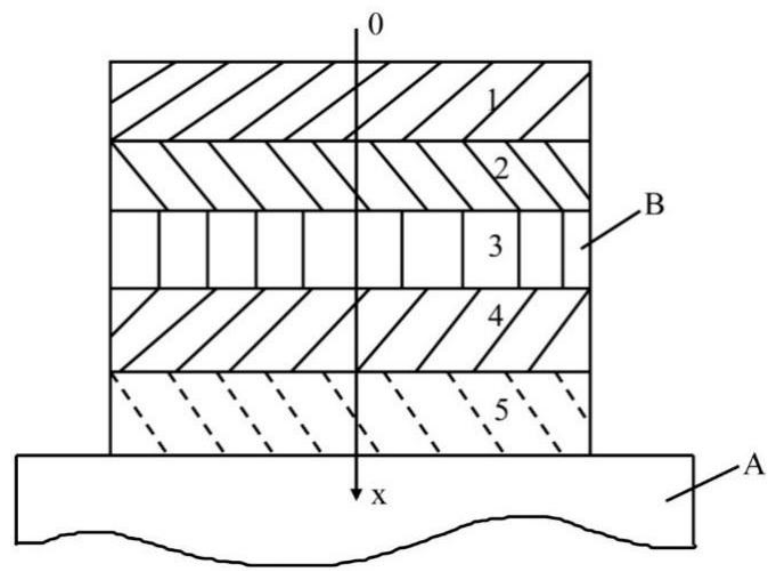

Figure 2.A trolley hearth of a tunnel kiln: A - trolley; B - sole with different material layers $(1,2,3,4,5)$

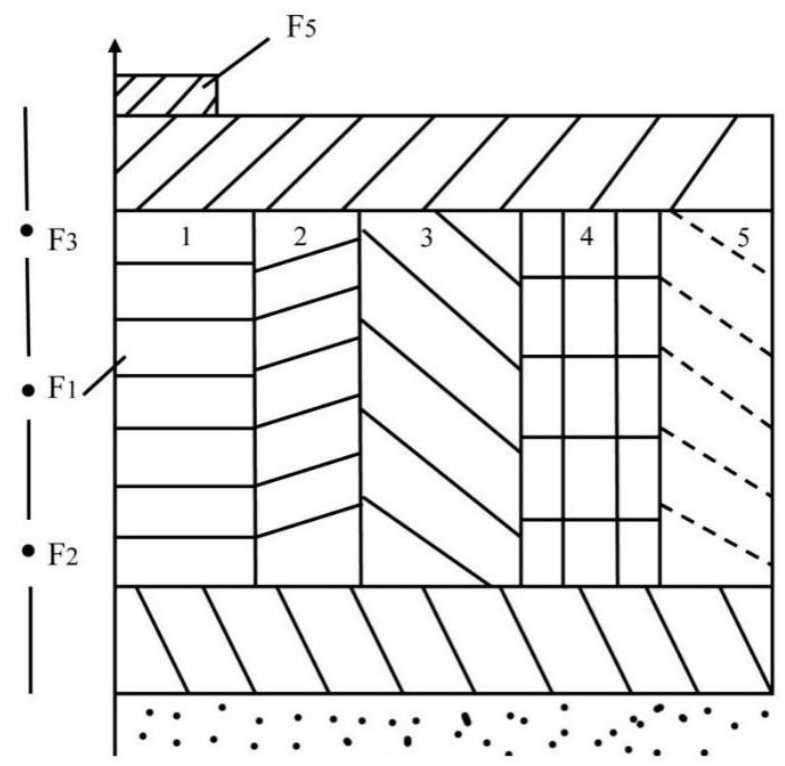

Figure 3. A diagram of a tunnel kiln wall 


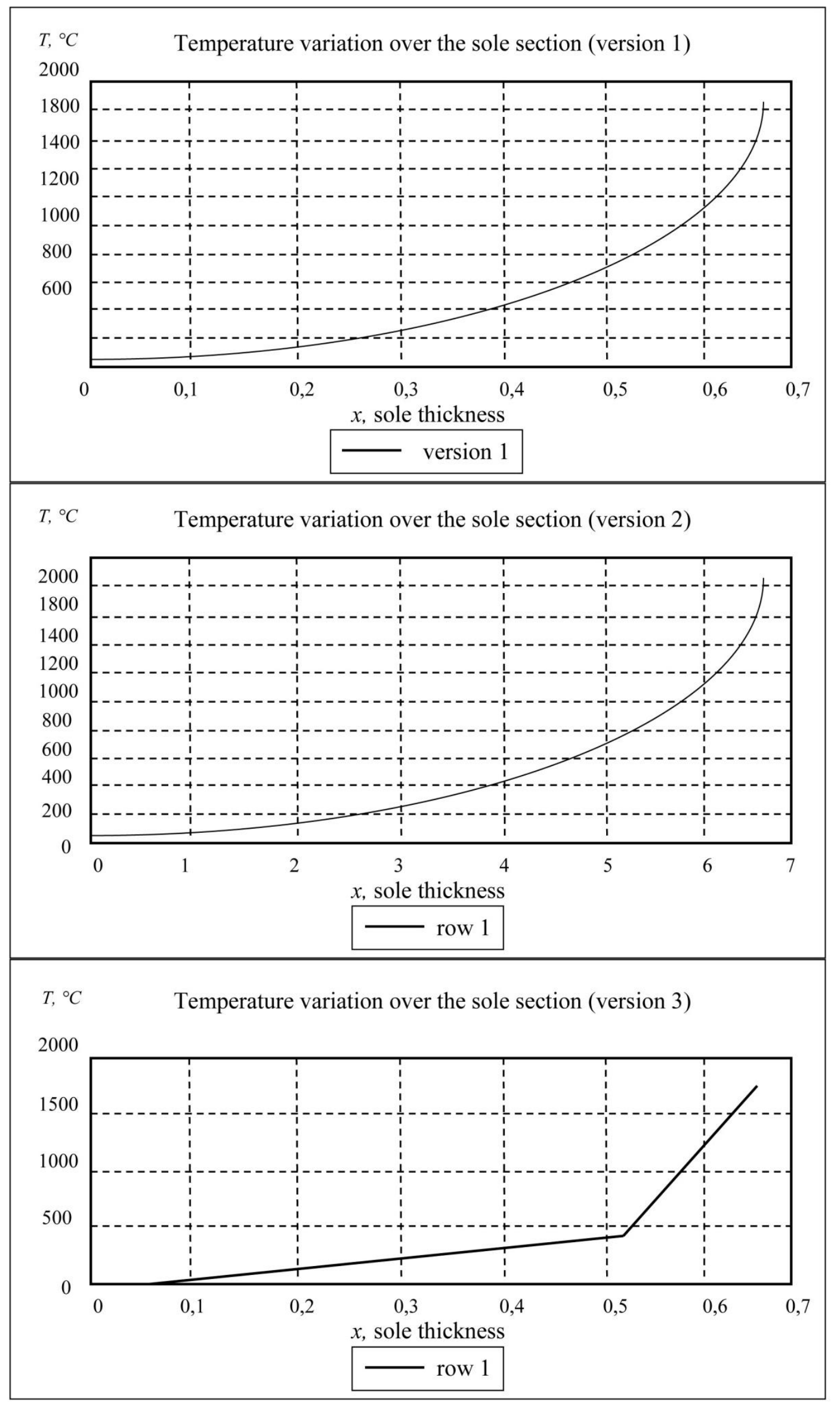

Figure 4.Temperature variation over trolley sole section 


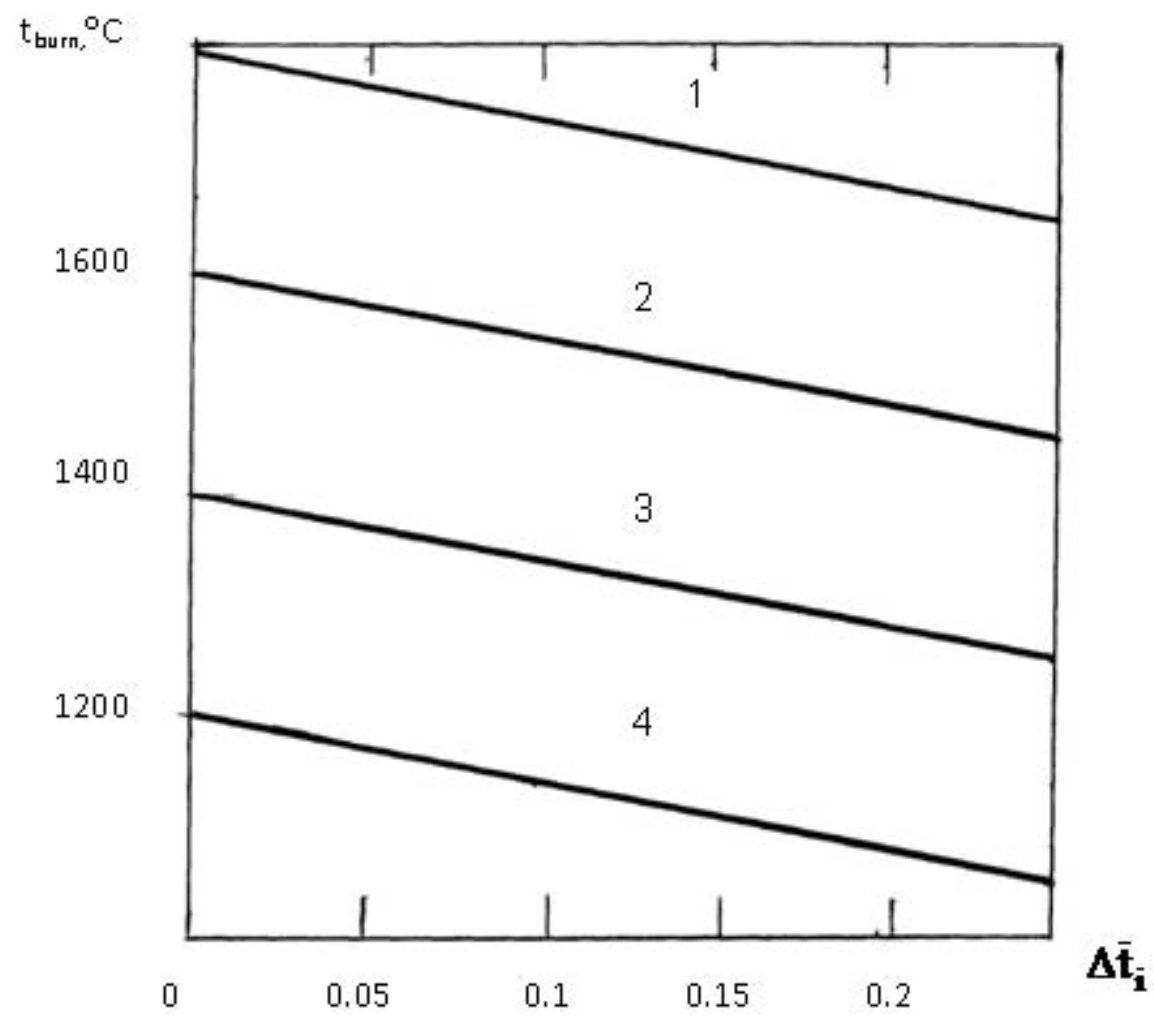

Figure 5.Dependence of burning temperature on hot air heat quantity (curves 1, 2, 3, 4 - Qha $=2,4,6$, $8 \mathrm{MJ} / \mathrm{m}^{3}$, respectively) and relative heat loss at the burning zone positions 
Table 1. The material composition of trolley sole of the tunnel kiln

\begin{tabular}{|c|c|c|c|c|}
\hline Version No & Layer No & Product materials & Layer thickness, mm & Density, $\mathrm{kg} / \mathrm{m}^{3}$ \\
\hline \multirow{5}{*}{ First } & 1 & $\begin{array}{l}\text { Compact corundum products } \\
\text { (PSH) }\end{array}$ & 130 & 3200 \\
\hline & 2 & $\begin{array}{l}\text { Mullite corundum products } \\
\text { (MK) }\end{array}$ & 130 & 2400 \\
\hline & 3 & $\begin{array}{l}\text { Mullite corundum products } \\
\text { (MK) }\end{array}$ & 130 & 2400 \\
\hline & 4 & Kaolin lightweight (KL-1) & 130 & 1300 \\
\hline & 5 & Chamotte lightweight (SHLB-1) & 130 & 1000 \\
\hline \multirow{5}{*}{ Second } & 1 & Periclase-spinel products & 130 & 3200 \\
\hline & 2 & Mullite corundum & 145 & 2400 \\
\hline & 3 & Corundum & 145 & 3300 \\
\hline & 4 & Chamotte crumb & 10 & 1000 \\
\hline & 5 & $\begin{array}{l}\text { Chamotte lightweight (SHL- } \\
0.8)\end{array}$ & 120 & 800 \\
\hline \multirow{5}{*}{ Third } & 1 & $\begin{array}{l}\text { Chrome-magnesite products } \\
\text { (XP) }\end{array}$ & 144 & 2900 \\
\hline & 2 & High-alumina corundum & 144 & 3300 \\
\hline & 3 & Kaolin light weight $(\mathrm{KL})$ & 130 & 1300 \\
\hline & 4 & $\begin{array}{l}\text { Chamotte lightweight (SHL- } \\
\text { 1.2) }\end{array}$ & 130 & 1200 \\
\hline & 5 & Chamotte crumb & 52 & 1000 \\
\hline
\end{tabular}

Table 2. Heat balance of preheating and burning zones of a high-temperature tunnel kiln

\begin{tabular}{|c|c|c|}
\hline \multirow[t]{2}{*}{ Heat balance item } & \multicolumn{2}{|c|}{ Quantity of incoming or outgoing } \\
\hline & MJ/hour & $\%$ \\
\hline 1 & 2 & 3 \\
\hline \multicolumn{3}{|l|}{ Heat income: } \\
\hline 1.Fuel heat & 116.5 & 89.9 \\
\hline 2. Physical heat introduced by fuel & 2.6 & 0.2 \\
\hline 3. Heat introduced into the burning zone by air coming from: & & \\
\hline the environment & 3.7 & 0.3 \\
\hline the cooling zone & 137 & 7.9 \\
\hline 4. Heat from products & 5.8 & 0.45 \\
\hline 5. Heat introduced by the trolley lining & 3.6 & 0.3 \\
\hline 6. Heat introduced by excess intake-air from the preheating zone & 12.3 & 0.95 \\
\hline Total: & 1296 & 100 \\
\hline \multicolumn{3}{|l|}{ Heat outgoing: } \\
\hline 7. Heating of products & 310 & 23.9 \\
\hline 8. Heating of the trolley lining & 171 & 13.2 \\
\hline 9. Losswithoutgoinggases & 317 & 24.5 \\
\hline 10. Heat loss into the environment through the lining & 998 & 39.4 \\
\hline Total: & 1296 & 100 \\
\hline
\end{tabular}


$\frac{d}{d x}\left(\lambda(T) \frac{d T}{d x}\right)+\frac{d}{d y}\left(\lambda(T) \frac{d T}{d y}\right)+\frac{d}{d z}\left(\lambda(T) \frac{d T}{d z}\right)=C(T) \rho \frac{d T}{d \tau}$

$\left.T\right|_{G}(x, y, z, \tau)=f(x, y, z)$,

$-\left.\lambda(T) \frac{d T}{d n}\right|_{G}=q_{n}(\tau)$

$-\left.\lambda(T) \frac{d T}{d n}\right|_{G}=\alpha\left[\left.T\right|_{G}-T_{\Gamma}(x, y, z, t)\right]$

$T(x, y, z, t)=F(x, y, z)$.

$D=\left\{(x, y, z) / 0 \leq x \leq l_{1}, \quad 0 \leq y \leq l_{2}, \quad 0 \leq z \leq l_{3}\right\}$,

$\bar{\Omega}_{h}=\left\{\left(x_{i}, y_{j}, z_{k}\right), x_{i}=i h_{1}, y_{j}=j h_{2}, z_{k}=k h_{3} ; 0 \leq i \leq N_{1}, 0 \leq j \leq N_{2}, 0 \leq k \leq N_{3}\right\}$

$x_{i-1 / 2} \leq X \leq x_{i+1 / 2}, y_{j-1 / 2} \leq Y \leq y_{j+1 / 2}, z_{k-1 / 2} \leq Z \leq z_{k+1 / 2}$

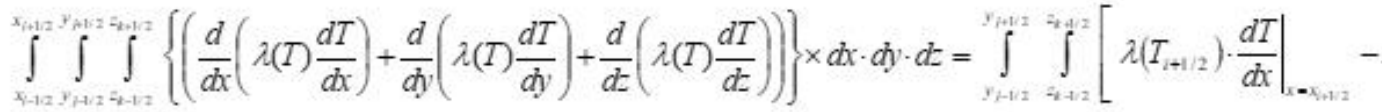

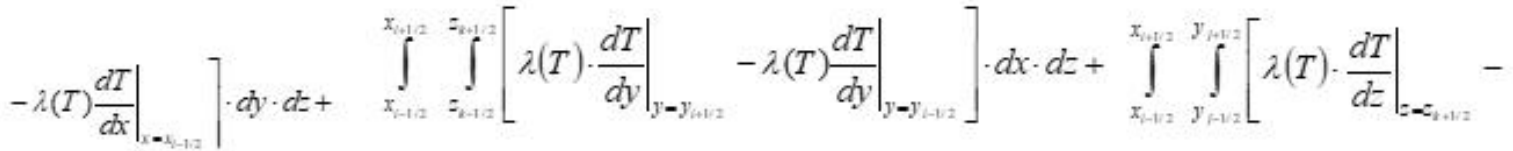

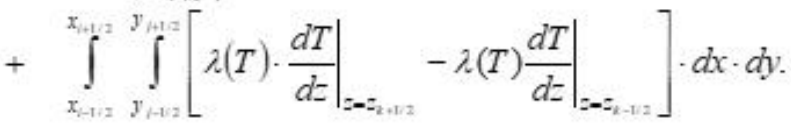

$\omega_{1}=+\lambda(T) \frac{d T}{d x}$

$\omega_{2}=+\lambda(T) \frac{d T}{d y}$

$$
\omega_{3}=+\lambda(T) \frac{d T}{d z}
$$

$\frac{d T}{d x}=\frac{\omega_{1}}{\lambda}$.

$$
T_{i, j, k}-T_{i-1, j, k}=\omega_{1, i-1 / 2} \int_{x_{i-1}}^{x_{i}} \frac{d x}{\lambda\left(x, y_{j}, z_{k}\right)}
$$




$$
\begin{aligned}
& \omega_{1, i-1 / 2, j_{k}} \approx a_{i j k} \frac{T_{i j k}-T_{i-1, j, k}}{h}=a_{i j k} T_{\bar{x}, i, j, k} ; \\
& \omega_{1, i+1 / 2, j_{k}}=a_{i+1 j k} T_{x, i, j, k} \\
& \left(a \cdot \Theta_{x}^{h}\right)_{x, i j k}+\left(a \cdot \Theta_{y}^{h}\right)_{y, i j k}+\left(a \cdot \Theta_{z}^{h}\right)_{z, i y k}=C_{i j k} \Theta_{t, y j k}^{h}, \\
& \left(a \cdot \Theta_{x}^{h}\right)_{x, j i k}=\frac{1}{h_{1}}\left[a_{i+1, j k} \frac{\Theta_{i+1, j k}^{h}-\Theta_{i, j k}^{h}}{h_{1}}-a_{i j k} \frac{\Theta_{i j k}^{h}-\Theta_{i-1 j k}^{h}}{h_{1}}\right] ; \\
& \left(a \cdot \Theta_{y}^{h}\right)_{y, j i k}=\frac{1}{h_{2}}\left[a_{i j+1, k} \frac{\Theta_{i, j+1, k}^{h}-\Theta_{i j k}^{h}}{h_{2}}-a_{i j x} \frac{\Theta_{i j k}^{h}-\Theta_{i j-1, k}^{h}}{h_{2}}\right] ; \\
& \left(a \cdot \Theta_{z}^{h}\right)_{z, j i k}=\frac{1}{h_{3}}\left[a_{i j k+1} \frac{\Theta_{i j k+1}^{h}-\Theta_{i j k}^{h}}{h_{3}}-a_{i j k} \frac{\Theta_{i j k}^{h}-\Theta_{i j k-1}^{h}}{h_{3}}\right] ; \\
& \Theta_{t, j i k}=\frac{\Theta_{i j k}^{h+1}-\Theta_{i j k}^{h}}{\tau} . \\
& \Theta_{0}=\mathrm{v}_{1} \Theta_{1}+\mu_{1} ; \quad \Theta_{N}=\mathrm{v}_{2} \Theta_{N-1}+\mu_{2} . \\
& C_{i}\left(T_{i}\right) \rho_{i} \frac{d T}{d t}=\frac{d}{d x}\left(\lambda_{i}\left(T_{i}\right) \frac{d T_{i}}{d x}\right), \quad i=1,2,3,4,5 . \\
& \left.T_{1}\right|_{x=0}=T_{p}(t) . \\
& -\left.\lambda_{1}\left(T_{1}\right) \frac{d T}{d x}\right|_{x=0}=\alpha\left(\left.T_{1}\right|_{x=0}\right)\left(\left.T_{1}\right|_{x=0}-T_{e n v}\right), \\
& -\left.\lambda_{5}\left(T_{5}\right) \frac{d T}{d x}\right|_{x=1}=\alpha\left(\left.T_{5}\right|_{x=1}\right)\left(\left.T_{1}\right|_{x=0}-T_{e n v}\right), \\
& \alpha(T)=A\left(T-T_{e n v}\right)^{0.25}+\varepsilon \sigma_{0} \frac{\left[\left(\frac{T+273}{100}\right)^{4}-\left(\frac{T_{e n v}+273}{100}\right)^{4}\right]}{\left(T-T_{e n v}\right)} . \\
& T(x, 0)=F(x),
\end{aligned}
$$

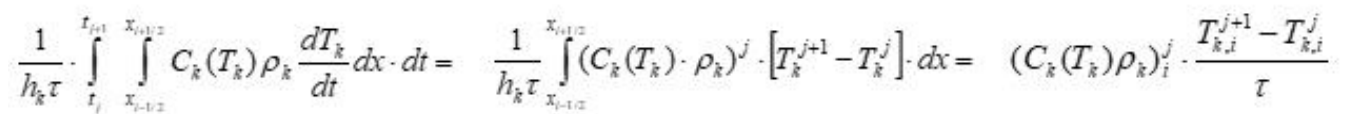




$$
\begin{aligned}
& \frac{1}{h_{k} \tau} \cdot \int_{t_{i}}^{t_{i+1}} \int_{x_{i=1 / 2}}^{x_{*+1} / 2} \frac{d}{d x}\left(\lambda_{k}\left(T_{k}\right) \frac{d T_{k}}{d x}\right) \cdot d x \cdot d t=\frac{1}{h_{k} \tau} \int_{t_{i}}^{t}\left[\lambda_{k}\left(T_{k}\right) \frac{d T_{k}}{d x}\right]_{i+1 / 2}=\left(\lambda_{k}\left(T_{k}\right) \frac{d T_{k}}{d x}\right)_{i-1 / 2} \cdot d \tau= \\
& =\frac{1}{h_{k}}\left[\left(\lambda_{k}\left(T_{k}\right) \frac{d T_{k}}{d x}\right)_{i+1 / 2}^{j+1}-\left(\lambda_{k}\left(T_{k}\right) \frac{d T_{k}}{d x}\right)_{i-1 / 2}^{j+1}\right] \approx \frac{1}{h_{k}^{2}}\left[\lambda_{k}\left(T_{k}\right)_{i+1 / 2}^{j} \cdot\left(T_{k, j+1}^{j+1}-T_{k, i}^{j+1}\right)-\left(\lambda_{k}\left(T_{k, i}^{j+1}-T_{k, i-1}^{j+1}\right)\right]\right. \\
& \left(C_{k}\left(T_{k}\right) \cdot \rho_{k}\right)_{i}^{j} \cdot \frac{T_{k, i}^{j+1}-T_{k, i}^{j}}{\tau}= \\
& =\frac{1}{h_{k}^{2}}\left[\lambda_{k}\left(T_{k}\right)_{i+1 / 2}^{j}\left(T_{k, i+1}^{j+1}-T_{k, i}^{j+1}\right)-\lambda_{k}\left(T_{k}\right)_{i-1 / 2}^{j}\left(T_{k, i}^{j+1}-T_{k, i-1} j+1\right)\right] . \\
& T_{1, N}^{j+1}=T_{p}^{j} \\
& -\lambda_{1}\left(T_{1, N}^{j}\right) \frac{T_{1, N}^{j+1}-T_{1, N-1}^{j+1}}{h_{1}}=\alpha \cdot T_{1, N}^{j} \cdot\left(T_{1, N}^{j+1}-T_{e n v}\right) \\
& -\lambda_{5}\left(T_{5,1}^{j}\right) \frac{T_{5,2}^{j+1}-T_{5,1}^{j+1}}{h_{5}}=\alpha\left(T_{5,1}^{j}\right)\left(T_{5,1}^{j+1}-T_{e n v}\right) \\
& T_{i}^{\mathrm{o}}=T^{\mathrm{O}}\left(x_{i}\right) \\
& A_{i+1 / 2}^{j}=\frac{\tau}{h_{k}^{2}} \frac{\lambda_{k}\left(T_{k}\right)_{i+1 / 2}^{j}}{\left(C_{k} \cdot T_{k} \cdot \rho_{k}\right)_{i}^{j}} ; \quad A_{i-1 / 2}^{j}=\frac{\tau}{h_{k}} \frac{\lambda_{k}\left(T_{k}\right)_{i-1 / 2}^{j}}{\left(C_{k} \cdot T_{k} \cdot \rho_{k}\right)_{i}^{j}} \\
& a_{i} y_{i-1}-b_{i y_{i}}+c_{i y_{i+1}}=d_{i} \text {. } \\
& A_{i-1 / 2} T_{k, i-1}^{j+1}-\left(1+A_{i-1 / 2}^{j}+A_{i+1 / 2}^{j}\right) \cdot T_{k, i}^{j+1}+A_{i+1 / 2}^{j} \cdot T_{k, i+1}^{j+1}=-T_{k}^{i} . \\
& a_{i}=A_{i-1 / 2}^{j} ; b_{i}=1+A_{i-1 / 2}^{j} ; c_{i}=A_{i+1 / 2}^{j} ; \alpha_{i}=-T_{k, i}^{j} . \\
& \frac{\left(C_{k} \cdot T_{k} \cdot \rho_{k}\right)_{i+1 / 2} \cdot\left(T_{k}^{j+1}-T_{k}^{j}\right)_{i+1 / 2}+\left(C_{k-1} \cdot T_{k-1} \cdot \rho_{k-1}\right)_{i-1 / 2}^{j} \cdot\left(T_{k}^{j+1}-T_{k}^{j}\right)_{i-1 / 2}}{2 \tau}= \\
& =\frac{1}{h_{k}+h_{k-1}}\left[\left(\lambda_{k}\left(T_{k}\right)\right)_{i+1 / 2}^{j} \cdot \frac{T_{k, i+1}^{j+1}-T_{k, i}^{j+1}}{h_{k}}-\left(\lambda_{k-1}\left(T_{k-1}\right)\right)_{i-1 / 2}^{j} \cdot \frac{T_{k, i}^{j+1}-T_{k, i-1}^{j+1}}{h_{k-1}}\right] \\
& q_{1}=\frac{\lambda_{1}\left(T_{N}+\lambda_{1}\left(T_{N-1}\right)\right) \cdot\left(T_{N}-T_{N-1}\right)}{2 h_{1}} . \\
& q_{2}=\alpha\left(T_{1}\right)\left(T_{1}-T_{e n v}\right) \\
& C_{p} \cdot V=\sum_{k=1}^{5}\left(\sum_{i=1}^{n_{k-1}} C_{k}\left(T_{k, i}\right) \cdot T_{k, i}\right) \cdot h_{k} \cdot \rho_{k}
\end{aligned}
$$


$C_{k}\left(T_{k}\right) \rho_{k} \frac{d T_{k}}{d T}=\frac{d}{d x}\left(\lambda_{k}\left(T_{k}\right) \frac{d T_{k}}{d x}\right)+\frac{d}{d t}\left(\lambda_{k}\left(T_{k}\right) \frac{d T_{k}}{d t}\right)$

$\left.T(x, z, t)\right|_{t=0}=T_{e n v}$.

$\left.T\right|_{F_{1}}=T_{p}(t)$

$\left.T\right|_{F_{1}}=T_{n}$.

$\left.\frac{d T_{k}}{d x}\right|_{F_{2}, \Gamma_{5}}=0$

$-\left.\lambda_{k}\left(T_{k}\right) \frac{d T_{k}}{d n}\right|_{F_{2}, F_{4}-F_{5}}=\alpha\left(\left.T\right|_{F_{2}, F_{4}-F_{5}}\right) \cdot\left(\left.T\right|_{F_{2}, F_{4}-F_{5}}-T_{e n v}\right)$

$\left.T_{2 p}\right|_{F_{4}, F_{6}}=T_{g r}$.

$C_{k}\left(T_{k}\right) \cdot \rho_{k} \frac{d T_{k}}{d t}=\alpha T_{k}$

$\alpha T_{k}=\left(\alpha_{1}+\alpha_{2}\right) \cdot T_{k} ; \alpha T_{k}=\frac{d}{d x}\left(\lambda_{k}\left(T_{k}\right)\right) \frac{d T_{k}}{d x} ;$

$\alpha_{2} \cdot T_{k}=\frac{d}{d z}\left(\lambda_{k}\left(T_{k}\right)\right) \frac{d T_{k}}{d z}$

$\omega_{h x_{k} h_{z}}=\left\{x_{i}=i h x_{k}, i=0, \ldots N_{1}, z_{j}=j h z_{k}, j=0, \ldots N_{2}\right\}, \ldots$

$\bar{\omega}=\sum_{k=1}^{z} \omega_{h x_{k}} \cdot h z_{k}$

$\int_{x_{i-1 / 2}}^{x_{i+1 / 2}} \int_{z_{i-1 / 2}}^{z_{i+1 / 2}} C_{k}\left(T_{k}\right) \cdot \rho_{k} \frac{d T}{d t} d x \cdot d z=\int_{x_{i-1 / 2}}^{x_{i+1 / 2}} \int_{z_{i-1 / 2}}^{z_{i+1 / 2}}\left[\frac{d}{d x}\left(\lambda_{k}\left(T_{k}\right) \frac{d T_{k}}{d x}\right)+\frac{d}{d z}\left(\lambda_{k}\left(T_{k}\right) \frac{d T_{k}}{d z}\right)\right] d x \cdot d z$

$\int_{x_{i-1 / 2}}^{x_{i+1 / 2}} \int_{z_{j-1 / 2}}^{z_{j+1 / 2}} C_{k}\left(T_{k}\right) \rho_{k} \frac{d T_{k}}{d t} \cdot d x \cdot d z \approx h_{x} h_{z}\left(C_{k}\left(T_{k}\right) \cdot \rho_{k}\right)_{i j}^{m} \cdot \frac{T_{k i j}^{m+1 / 2}-T_{k i j}^{m}}{0.5 \cdot \tau}$ 


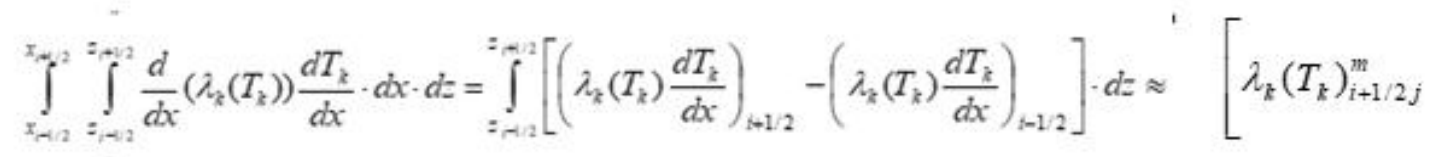

$$
\begin{aligned}
& \left.\frac{T_{k i+i j}^{m+1 / 2}-T_{k i j}^{m+1 / 2}}{h_{x}}-\lambda_{k}\left(T_{k}\right)_{i-1 / 2 j}^{m} \frac{T_{k i j}^{m+1 / 2}-T_{k i-j}^{m+1 / 2}}{h_{x}}\right] \\
& \int_{x_{i-1 / 2}}^{x_{i+1 / 2}} \int_{z_{-1 / 2}}^{z_{+1 / 2}} \frac{d}{d z}\left(\lambda_{k}\left(T_{k}\right)\right) \frac{d T_{k}}{d z} \cdot d x \cdot d z \approx h_{x}\left[\lambda_{k}\left(T_{k}\right)_{i j+1 / 2 j}^{m} \frac{T_{k i j+1}^{m}-T_{k i j}^{m}}{h_{z}}-\lambda_{k}\left(T_{k}\right)_{i j-1 / 2}^{m} \frac{T_{k i j}^{m}-T_{k j-1}}{h_{z}}\right] \\
& \left(C_{k}\left(T_{k}\right) \cdot \rho_{k}\right)_{i j}^{m} \frac{T_{k j}^{m+1 / 2}-T_{k i j}^{m}}{0.5 \cdot \tau}=\frac{1}{h^{2} x}\left[\left(\lambda_{k}\left(T_{k}\right)\right)_{i+1 / 2 j}^{m} \cdot\left(T_{k i+1 j}^{m+1 / 2}-T_{k j}^{m+1 / 2}\right)-\left(\lambda_{k}\left(T_{k}\right)\right)_{i-1 / 2 j}^{m}\left(T_{k i j}^{m+1 / 2}-T_{k i-1 j}^{m+1 / 2}\right]+\right. \\
& +\frac{1}{h^{2} z}\left[\left(\lambda_{k}\left(T_{k}\right)\right)_{i+1 / 2 j}^{m} \cdot\left(T_{k i j+1}^{m}-T_{k i j}\right)-\left(\lambda_{k}\left(T_{k}\right)\right)_{i j-1 / 2}^{m} \cdot\left(T_{k j}^{m}-T_{k i j-1}^{m}\right]\right. \\
& \left(C_{k}\left(T_{k}\right) \cdot \rho_{k}\right)_{i j}^{m} \frac{T_{k i j}^{m+1}-T_{k i j}^{m+1.2}}{0.5 \cdot \tau}=\frac{1}{h^{2} x}\left[\left(\lambda_{k}\left(T_{k}\right)\right)_{i+1 / 2 j}^{m} \cdot\left(T_{k i+1 j}^{m+1 / 2}-T_{k i j}^{m+1 / 2}\right)-\left(\lambda_{k}\left(T_{k}\right)\right)_{i-1 / 2 j}^{m}\left(T_{k i j}^{m+1 / 2}-T_{k i-1 j}^{m+1 / 2}\right]+\right. \\
& +\frac{1}{h^{2}-}\left[\left(\lambda_{k}\left(T_{k}\right)\right)_{i j+1 / 2}^{m} \cdot\left(T_{k i j+1}^{m+1}-T_{k i j}^{m+1}\right)-\left(\lambda_{k}\left(T_{k}\right)\right)_{i j-1 / 2}^{m} \cdot\left(T_{k i j}^{m+1}-T_{k j-1}^{m+1}\right]\right. \\
& \frac{\left(C_{k} \cdot T_{k-1} \cdot \rho_{k-1}\right)_{i-1 / 2 j}^{m}+\left(C_{k} \cdot T_{k} \cdot \rho_{k}\right)_{i+1 / 2 j}^{m}}{2} \cdot \frac{T_{k j i}^{m+1 / 2}-T_{k j j}^{m}}{0.5 \cdot \tau}=\frac{1}{h^{2} x}\left[\left(\lambda_{k}\left(T_{k}\right)\right)_{i+1 / 2 j}^{m} \cdot\left(T_{k i+1 j}^{m+1 / 2}-T_{k i j}^{m-1 / 2}\right)-\left(\lambda_{k-1}\left(T_{k-1}\right)\right)_{i-1 / 2 j}^{m}\right. \\
& \left(T_{k i j}^{m+1 / 2}-T_{k i-1 j}^{m+1 / 2}\right]+\frac{1}{h^{2} z}\left[\left(\lambda_{k}\left(T_{k}\right)\right)_{i j+1 / 2}^{m} \cdot\left(T_{k j+1}^{m}-T_{k i j}^{m}\right)-\left(\lambda_{k-1}\left(T_{k-1}\right)\right)_{j i-1 / 2}^{m} \cdot\left(T_{k i j}^{m}-T_{k i j-1}^{m}\right]\right. \\
& \frac{\left(C_{k-1}\left(T_{k-1}\right) \rho_{k-1}\right)_{i-1 / 2 j}^{m}+\left(C_{k}\left(T_{k}\right) \cdot \rho_{k}\right)_{i+1 / 2 j}}{2} \cdot \frac{T_{k y}^{m+1}-T_{k j}^{m+1 / 2}}{0.5 \tau}=\frac{1}{h^{2} x}\left[\left(\lambda_{k}\left(T_{k}\right)\right)_{i+1 / 2 j}^{m} \cdot\left(T_{k+1 j}^{m+1 / 2}-T_{k j}^{m+1 / 2}\right)-\left(\lambda_{k-1}\left(T_{k-1}\right)\right)_{j-1 / 2}^{m}\right. \\
& \left(T_{k i j}^{m+1}-T_{k j-1}^{m+1}\right]+\frac{1}{h^{2} z}\left[\left(\lambda_{k}\left(T_{k}\right)\right)_{i j+1 / 2}^{m} \cdot\left(T_{k j-1}^{m+1}-T_{k i j}^{m+1}\right)-\left(\lambda_{k-1}\left(T_{k-1}\right)\right)_{i j-1 / 2}^{m} \cdot\left(T_{k j}^{m+1}-T_{k j-1}^{m+1}\right]\right. \\
& a_{v} y_{v}-b_{v} y_{v}+c_{v} y_{v+1}=d_{v} \\
& Q_{1}=Q_{H}^{p} \cdot B, \\
& Q_{2}=C_{T} \cdot t_{T} \cdot B \\
& Q_{3}^{\prime}=2 / 3 V_{B} \cdot C_{B} \cdot t_{B} \cdot \alpha \cdot B_{G} \\
& Q_{3}^{\prime \prime}=1 / 3 V_{B} \cdot C_{B} \cdot t_{B} \cdot \alpha \cdot B \\
& Q_{4}=P \cdot C_{p r} \cdot t_{p r}
\end{aligned}
$$


$Q_{5}=1 / 8\left(G_{c m} C_{c m}+G_{c} C_{c}+G_{k l} C_{k l}+G_{c l} C_{c l}+G_{c c} C_{c c}\right) t_{t r}$,

$Q_{6}=V_{B}\left(\alpha_{o g}-\alpha\right) \cdot t_{B} \cdot C_{B} \cdot B$

$Q_{7}=P \cdot C_{p r}\left(t_{\kappa}-t_{H}\right)$,

$q_{a c}=q_{m}^{B}-q_{0}^{B}$,

$Q_{9}=V_{c p r} \cdot t_{c p r} \cdot \alpha_{o g} \cdot B_{G} \cdot C_{c p r}, \cdot$

$Q_{10}=\frac{t_{i s}-t_{a a}}{\frac{\delta_{1}}{\lambda_{1}}+\frac{\delta_{2}}{\lambda_{2}}+\ldots+\frac{\delta_{i}}{\lambda_{i}}+\frac{1}{\alpha_{o}}} \cdot F$,

$B_{i} \cdot Q_{u}^{p}+B_{i} \cdot V_{h a}=Q_{c p}^{i}+Q_{r}^{i}+Q_{t r}^{a c}+Q_{t r}^{m}+C_{c p r} \cdot t_{c p r} \cdot V_{c p r} \cdot B_{i}+Q_{d i s s}^{i} \cdot$

$V_{G}=\frac{Q_{G} \cdot\left(Q_{m}^{i}+\sum Q_{n}^{i}+Q_{d i s s}^{i}\right)+\sum_{0}^{i=1} V_{c p r}}{Q_{H}^{p}+\sum Q_{n}+\alpha_{i} V_{o} J_{a h}}$.

$\Delta t_{i}=\frac{\sum\left(Q_{n}+Q_{m}\right)+Q_{\text {diss }}}{C_{c p r} \cdot t_{c p r} \cdot V_{c p r}}$.

$V_{h a}=Q_{h a} / t_{h a} \cdot C_{h a}, \mathrm{~m}^{3} /$ hour.

$V_{h a}^{i}=\mathrm{V}_{h a} \cdot B_{i}, \mathrm{~m}^{3} /$ hour.

$V_{i a}=10 \cdot V_{h a} ; \quad V_{i a}^{i}=V_{i a} \cdot B_{i}$

you give appropris This article is licensed under a Creative Commons Attribution 4.0 (CC BY 4.0) International License, which permits use, sharing, adaptation, distribution, and reproduction in any medium or format, as long as 